\title{
Tiroid tümörlerinin istatistiksel olarak incelenmesi: 10 yıllık retrospektif bir çalışma
}

\section{Statistical evaluation of thyroid tumors: a 10-year retrospective study}

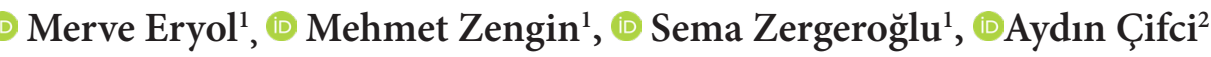

${ }^{1}$ Kırıkkale Üniversitesi Tıp Fakültesi, Tıbbi Patoloji Anabilim Dalı, Kırıkkale, Türkiye

${ }^{2}$ Kırıkkale Üniversitesi Tıp Fakültesi, İç Hastalıkları Anabilim Dalı, Kırıkkale, Türkiye

Cite this article as/Bu makaleye atıf için: Eryol M, Zengin M, Zergeroğlu S, Çifci A. Tiroid tümörlerinin istatistiksel olarak incelenmesi: 10 yllık retrospektif çalışma. J Med Palliat Care 2020; 1(4): 98-102.

\section{ÖZ}

Amaç: Tiroid tümörleri baş-boyun maligniteleri arasında en sık görülen tümörlerdendir. Bu çalışmada bölümümüzde tanı almış tiroid kanseri olguları literatür bilgileri eşliğinde incelendi.

Gereç ve Yöntem: 2010-2020 yılları arasında opere edilmiş tüm tiroid kanser hastaları çalışmaya dahil edildi. Olguların klinikopatolojik özellikleri istatistiksel olarak analiz edildi.

Bulgular: Tiroid tümörleri kadınlarda erkeklere göre 4 kat fazla görüldü. Hastalarımızın \%48,7’i 40-59 yaş grubunda, \%32,8’si 20-39 yaş grubunda yer almakta idi. Olguların \%80,6'sında lokalize tümör, \%18,4'ünde ise metastatik tümör mevcut idi. Tiroid kanserleri kadınlarda 40-49 yaş aralığında en yüksek oranda; erkeklerde ise 50-59 yaş aralığında en yüksek oranda saptandı. Lokalize tümör evresi \%65,3 ile en yüksek oranda tespit edildi. Ayrıca kadınlara \%69,8 erkeklerde ise \%54,7 oranlarında lokalize tümör evresi saptandı. Tiroid kanserlerinin cinsiyet açısından dağılımı araştırıldığında, evre $(p<0,001), y a s ̧(p<0,0001)$ ve lenf nodu durumu ( $\mathrm{p}<0,05)$ açısından istatistiksel olarak anlamlı fark görüldü.

Sonuç: Bulgularımız ülkemizde tiroid tümörlü olguların erken teşhisinin oldukça arttığını göstermektedir. Ayrıca istatistiksel sonuçlarımız literatür ile benzerdi ve bu durum ülkemizin tiroid tümörlerinin yönetiminde başarılı olduğunu göstermektedir.

Anahtar Kelimeler: Tiroid tümörleri, baş-boyun tümörleri, prognostik parametreler

\begin{abstract}
Objective: Thyroid tumors are among the most common head and neck malignancies. In this study, thyroid cancer cases diagnosed in our department were examined in the light of the literature.

Material and Method: All thyroid cancer patients operated between 2010 and 2020 were included in the study. The clinicopathological features of the cases were analyzed statistically.

Results: Thyroid tumors were seen 4 times more in women than men. $48.7 \%$ of our patients were in the $40-59$ age group, and $32.8 \%$ were in the $20-39$ age group. Localized tumor was present in $80.6 \%$ of the cases, and metastatic tumor was present in $18.4 \%$. Thyroid cancers were found with the highest rate in the 40-49 age range in women and the highest rate in the 5059 age range in men. Localized tumor stage was determined with the highest rate with $65.3 \%$. Also, localized tumor stages were detected in $69.8 \%$ of women and $54.7 \%$ of men. When the distribution of thyroid cancers by gender was investigated, a statistically significant difference was found in terms of stage $(\mathrm{p}<0.001)$, age $(\mathrm{p}<0.001)$, and lypmh node status $(\mathrm{p}<0.05)$.

Conclusion: Our findings show that the early diagnosis of patients with thyroid tumors has increased considerably in our country. Also, our statistical results were similar to the literature and this shows that our country is successful in the management of thyroid tumors.
\end{abstract}

Keywords: Thyroid tumors, head and neck tumors, prognostic parameters 


\section{GIIRIŞ}

Tiroid kanserleri kadınlarda 2. en sık; erkeklerde ise 8 . en sık görülen kanser türüdür $(1,2)$. Tiroid kanserlerinin \%94,4'ü papiller tiroid karsinomu (PTK) , \%3,4’ü foliküler tiroid karsinomu (FTK), \%1,9'u ise medüller tiroid karsinomu (MTK) alt tipindedir $(1,2)$. Tiroid kanserleri kadın cinsiyette daha sık izlenmekte ve ilerleyen yas ile birlikte prognoz daha kötü seyretmektedir. Tiroid kanserli hastalar genellikle asemptomatik olmakla beraber en sık izlenen semptomlar boyunda şişlik, ağrı, ses kısıklığı ve yutma güçlüğüdür $(1,2)$. Hastalarda genellikle ötiroidi saptanır, hipertiroidi ya da hipotiroidi bulguları görülmez. Tiroid kanseri gelişiminde çevresel faktörler ile genetik predispozisyonun ortak etkisinin varlığı söz konusudur. Radyasyon maruziyeti ve özellikle FTK'da iyot eksikliği bilinen en önemli risk faktörlerindendir $(1,2)$. PTK'larda BRAF ve RAS gen mutasyonları, FTK'larda PAX8/PPARVgen re-arranjmanı ve MTK'larda RET gen mutasyonları izlenmektedir.

Ylllar içinde tiroid kanser insidansı artış göstermesine rağmen kür şansı yüksek bir kanser türü olduğundan mortalitede belirgin bir değişiklik izlenmemiştir (3). Tiroid kanserlerindeki insidansın artışı, görüntüleme tekniklerinin gelişimi ile tespit edilme oranlarının artışına bağlanmaktadır. Tiroid kanserleri için 5 yıllık mortalite oranları yaklaşı \%20-30 olarak bildirilmektedir (4). $\mathrm{Bu}$ çalışmada bölümümüzde tanı almış tiroid kanseri hastalarında izlenen prognostik parametreler literatür bilgileri eşliğinde analiz edildi.

\section{GEREÇ VE YÖNTEM}

\section{Etik Onay}

Çalışmamız için Kırıkkale Üniversitesi Girișimsel Olmayan Etik Kurulu’ndan onay alınmıștır (2020.11.03). Çalışmamız boyunca yapılan tüm işlemlerin 1964 Helsinki Bildirgesi'ne ve ulusal/kurumsal etik standartlara uygun olmasına özen gösterildi.

\section{Çalıșmanın Tasarımı ve Veri Toplama}

Araștırmamı Kırıkkale Üniversite Tip Fakültesi’nde yürütüldü. Bu çalışmaya 2010-2020 yılları arasında tiroid kanseri nedeniyle Kırıkkale Üniversitesi Tip Fakültesi Hastanesinnde opere edilmiş 161 vaka dahil edilmiştir. Ameliyat sonrası ilk 1 ay içerisinde ölen $(n=2)$, tanı sirasında sekonder malignitesi olan $(\mathrm{n}=1)$ ve hastane veri tabanındaki bilgileri eksik olan hastalar $(\mathrm{n}=5)$ çalıșma dıșı bırakıldı. Sonuç olarak; 153 olgu çalışmaya alındı. Olgulara ait klinik ve patolojik veriler Kırıkkale Üniversitesi veri tabanından temin edildi. Bu bilgiler yaş, cinsiyet, tümör boyutu, pT evresi, histolojik alt tipi ve lenf nodu durumu verilerini içermekte idi.

\section{İstatistiksel Analiz}

Veriler not edilirken yüzde, frekans, aralık, ortalama ve standart sapma kullanıldı. Tiroid kanserleri ile klinikopatolojik değișkenler arasındaki ilișki Ki-kare testi ile analiz edildi. 0,05 değeri p için anlamlılık sinırı olarak kabul edildi. Tüm analizler için SPSS 21.0 (IBM Institute, North Castle, USA) programı kullanıldı.

\section{BULGULAR}

\section{Genel Bulgular}

Olgularımızın \%81,8'inin kadın cinsiyette olduğu görüldü. Olgularımızın \%48,7'si 40-59 yaş aralığında; \%32,8’i 2039 yaş aralığında yer almakta idi. 20 yaş altında sadece $\% 2,4$ olgu yer almakta idi. Hastaların \%80,6'sında tümör lokalize iken; \%18,4'ünde metastaz mevcut idi. Olguların \%94,1'i PTK olarak tespit edilmiștir. PTK olgularının $\% 35,7$ 'si klasik papiller, \%34,4’ü foliküler tip ve $\% 25,3$ 'ü mikrokarsinom olarak tespit edilmiştir (Resim 1-4).

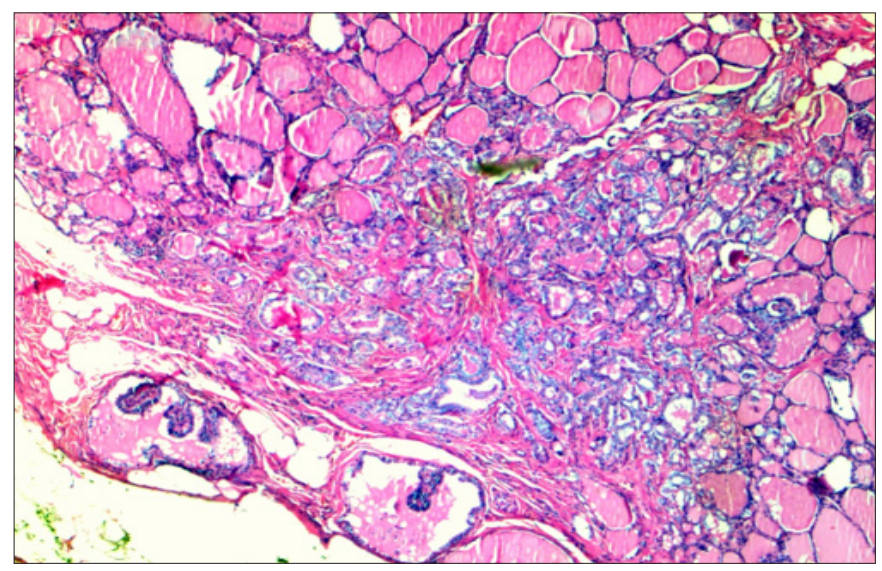

Resim 1. Papiller mikrokarsinom. Burada $1 \mathrm{~cm}$ 'den küçük bir papiller karsinom odağı görülmektedir (x4, H\&E).

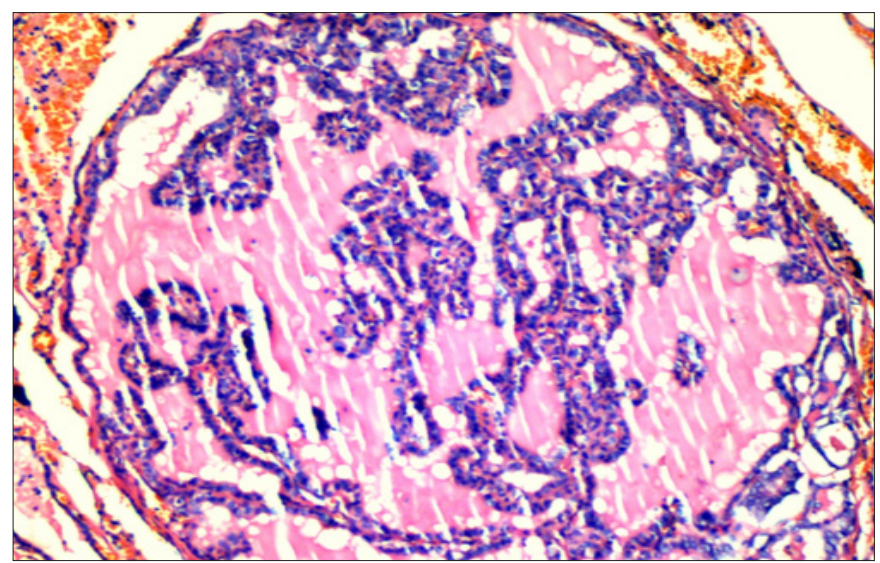

Resim 2. Klasik papiller karsinom. Burada klasik papiller karsinomdaki papillalar görülmektedir (x10, H\&E).

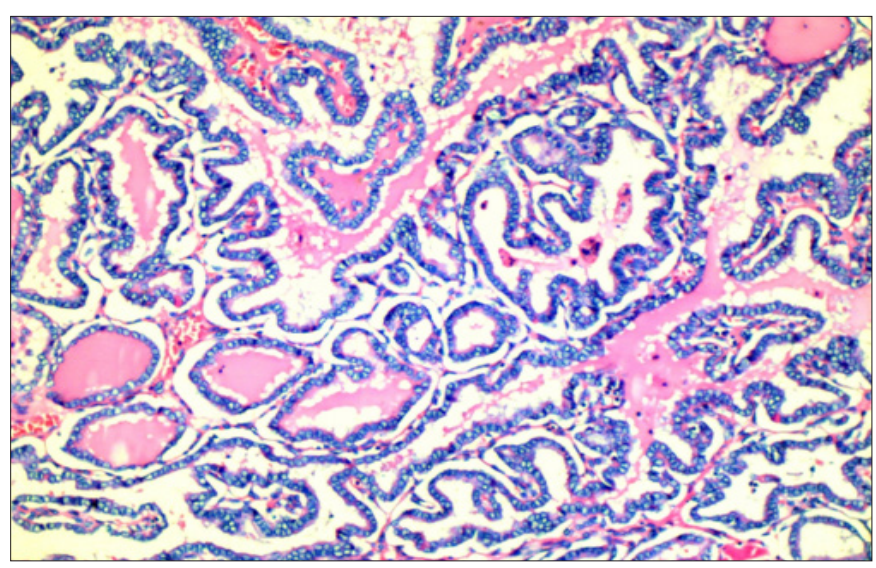

Resim 3. Klasik papiller karsinom. Burada klasik papailler karsinomda nükleer berraklaşma ve kontür bozuklukları görülmektedir (x10, H\&E). 


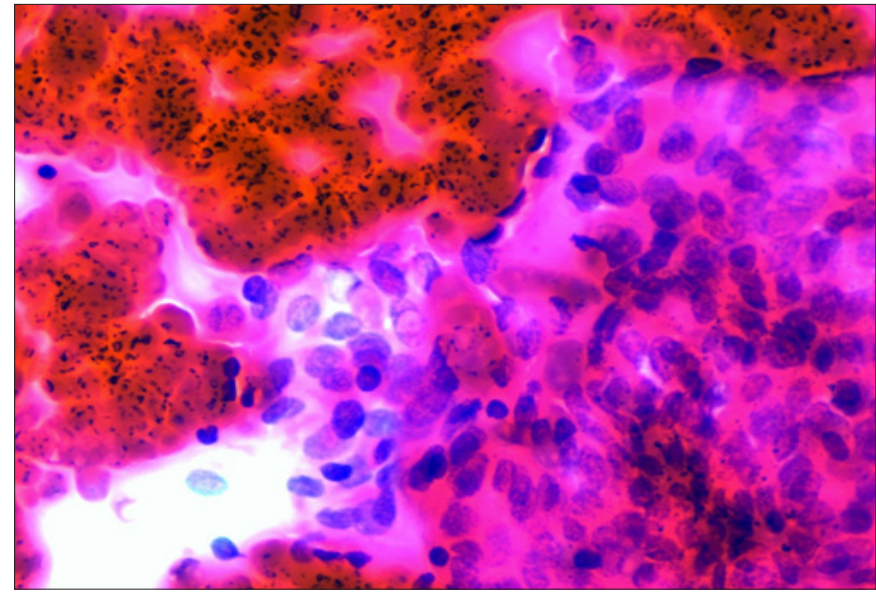

Resim 4. Papiller karsinom sitolojisi. Burada papiller karsinom sitolojisinde tiroid hücrelerinde nükleer irileşme, kontür bozukluğu ve Groove varlığı görülmektedir (x20, PAP).

\section{Tiroid Tümörleri ve Cinsiyet Arasındaki İlişki}

Çalışmamızda tiroid tümörlerinin kadınlarda erkeklere nazaran 4 kat fazla izlendiği tespit edilmiştir. Cinsiyetin yaş gruplarıyla ilişkisi incelendiğinde, tiroid tümörleri kadınlarda 40-49 yaş aralığında en yüksek oranda, erkeklerde ise 50-59 yaş aralığında en yüksek oranda saptanmıştır. Cinsiyetin evre gruplarıyla ilişkisi incelendiğinde lokalize tümör evresi \%65.3 ile en yüksek oranda tespit edildi. Cinsiyetin evre gruplarına göre dağılımı analiz edildiğinde kadınlarda \%69.8, erkeklerde ise \%54.7 oranlarında lokalize tümör evresi saptanmıştır. Her iki cinsiyet (erkeklerde: \%18.3, kadınlarda: \%14.6) için lokal ileri evre ikinci sıklıkta idi. Tiroid tümörlerinin cinsiyet ile ilişkisi istatistiksel olarak analiz edildiğinde evre $(\mathrm{p}<0.001)$, yaş $(\mathrm{p}<0.001)$ ve lenf nodu durumu $(\mathrm{p}<0.05)$ açısından istatistiksel olarak anlamlı fark bulunmuştur. Diğer taraftan $\mathrm{pT}$ ile tümör boyutu $(\mathrm{p}<0.05)$ ve lenf nodu durumu $(\mathrm{p}<0.05)$ arasinda da anlamlı ilişki mevcuttu (Tablo 1).

\section{Tiroid Tümörleri ve Yıl Arasındaki İlişki}

Olguların yıllara göre dağılımı incelendiğinde, hastaların \%42,7'sinin 2015-2020 y1lları arasinda tanı aldığg görülmüştür. Tümörlerin yıllara göre artış-azalışı incelendiğinde 10 ylllık dönemde her iki cinsiyette belirgin olarak artış görüldü. Tümörlerdeki yıllara göre evre değişimi incelendiğinde lokalize tümör olgularının yıllara göre belirgin artış içerisinde olduğu, metastatik grubun ise azalma yönünde eğilimi olduğu tespit edilmiştir. Analizlere çoklu olarak bakıldığında kadın tiroid tümörlü hastaların 2015-2020 yılları arasinda tanı alan, 20-49 yaş grubunda, lokalize tümör evresinde olgular olduğu görüldü. Erkek tiroid tümörlü hastaların genellikle 40-59 yaş aralığında olduğu ve metastatik olguların ise genellikle 2010-2015 yilları arasinda tanı aldığ 1 tespit edildi. Ayrıca 20 yaş altındaki tüm tiroid kanserli olguların 2015-2020 yılları arasında tanı aldığ görülmüştür.

\section{TARTIŞMA}

Tiroid kanserleri mortalite oranları en düşük olan tümörlerdendir. Literatür verilerine göre dünya genelinde akciğer kanserine bağlı ölüm birinci sırada iken; tiroid kanserlerine bağlı ölüm 24. sırada yer almaktadır (5). Ayrıca tiroid kanseri saptanan hastaların \%15,9'u 20-34 yaş aralığında, \%18,2'si 35-44 yaş aralığında, \%22,2'si 45-54 yaş aralığındadır ve vakaların sadece \%1,8'i 20 yaş altındadır $(5,6)$. Bu verilere göre vakaların en sık görüldüğü yaş 45-54 aralığıdır. Tiroid kanserlerinin kadınlarda görülme sıklığı erkek cinsiyete kıyasla 3 kat fazladır (7). Çalışmamızda izlenen bulgular literatür bilgisi ile uyumlu olup tiroid kanserlerinin hastanemizde baş boyun kanserleri içerisinde kadınlarda en sık karşılaşılan tümörler olduğu görüldü.

Teknolojikgelişmelerlebirliktegörüntülemetekniklerinin gelişmesi ve toplumsal farkındalığın artışı ile birlikte tiroid kanserlerinin insidansında yıllar içerisinde belirgin bir artış meydana gelmiştir $(8,9)$. Bir çalışmaya göre görüntüleme yöntemleri kullanılmıyor olsa, Amerika Birleşik Devletleri'nde 1998-2007 yılları arasında tanı alan hastaların \%70-80'i asemptomatik olarak kalacak ve yaşamları boyunca tiroid lezyonları saptanmayacaktı (9). Tiroid cerrahisindeki komplikasyonlar göz önüne alındığında özellikle asemptomatik, risk faktörü bulunmayan ve $<1 \mathrm{~cm}$ nodülü olan hastalarda ileri tetkik önerilmemektedir (9). Literatür bilgisi ile uyumlu olarak vakalarımız içerisinde lokalize tümör olgularının yıllara göre belirgin artış içerisinde olduğunu, metastatik olguların ise azaldığı tespit edilmiştir.

Tablo 1. Tiroid tümörlerinin istatistiksel analizi. Burada prognostik parametrelerin birbiri arasındaki istatistiksel ilişki görülmektedir. Anlamlı sonuçlar koyu ve italik yazılmıştır.

\begin{tabular}{|c|c|c|c|c|c|}
\hline Ki-Kare Test & $\begin{array}{c}\text { Yaş } \\
\text { (cut-off: } 50 \text { yaş) }\end{array}$ & $\begin{array}{c}\text { Cinsiyet } \\
\text { (kadın/erkek) }\end{array}$ & $\begin{array}{l}\text { Tümör boyutu } \\
\text { (cut-off: } 2 \mathrm{~cm} \text { ) }\end{array}$ & $\begin{array}{c}\mathrm{pT} \\
(\mathrm{pT} 1-2 / \mathrm{pT} 3-4)\end{array}$ & $\begin{array}{c}\text { Lenf Nodu } \\
\text { (pozitif/negatif) }\end{array}$ \\
\hline Yaş (cut-off: 50 yaş) & - & - & - & - & - \\
\hline Cinsiyet (kadın/erkek) & $\mathrm{p}<0,001$ & - & - & - & - \\
\hline Tümör boyutu (cut-off: $2 \mathrm{~cm}$ ) & $\mathrm{p}=0,358$ & $\mathrm{p}=0,296$ & - & - & - \\
\hline $\mathrm{pT}(\mathrm{pT} 1-2 / \mathrm{pT} 3-4)$ & $\mathrm{p}=0,246$ & $\mathrm{p}<0,001$ & $\mathrm{p}=0,653$ & - & - \\
\hline Lenf nodu (pozitif/negatif) & $\mathrm{p}=0,435$ & $\mathrm{p}=0,032$ & $\mathrm{p}=0,026$ & $\mathrm{p}=0,018$ & - \\
\hline
\end{tabular}


Diferansiye tiroid kanserlerinde evreleme genellikle cerrahi rezeksiyon sonrasi serum tiroglobulin seviyesinin ölçümü ve radyoaktif iyot ölçümü ile yapılır. Anaplastik karsinom, MTK gibi histolojik tiplerde ise pozitron emisyon tomografisi ile değerlendirme yapılır (10). İnce iğne aspirasyon biyopsi ile anaplastik karsinom gibi agresif gidişli histolojik tipler saptanan hastalarda ise operasyon öncesi boyun ve toraks bilgisayarlı tomografi ile lokal ve uzak yaylım varlığ 1 açısından inceleme gereklidir. MTK'da serum kalsitonin ve karsiyoembriyojenik antijen seviyeleri de incelenmelidir $(10,11)$. Çalışmamızda bu alt tipler oldukça düşük oranda izlenmiştir ve ayrıca analize tabi tutulmamıştır.

PTK'ların lenfatik yayılım yoluyla bölgesel lenf nodlarını tutma eğilimi vardır ve ilk tanı anında vakaların \%20 -90'ında bölgesel lenf nodu metastazı saptanmaktadır $(10,11)$. Hastaların çok az bir kısmı tanı anında uzak metastatik hastalık evresindedir. Geniş bir seride boyun ve mediasten dışı metastaz varlığı PTK'da \% 1-2 arasında iken, FTK için bu oran \%2-5 olarak verilmiştir (12-14). Çalışmamızda literatür ile uyumlu olarak vakaların büyük çoğunluğu lokalize tümör evresindedir. Ayrıca kadın cinsiyette bu oranın erkek cinsiyete kıyasla daha yüksek olduğu görüldü.

Hem lokalize hem metastatik formlar ele alındığında tiroid karsinomlarının prognozu oldukça iyidir. Genel olarak 5 yıllık sağkalım oranları \%70 civarında olmakla beraber PTK için bu oran \%95; FTK için $\% 80$; MTK için \%65 olarak verilirken, anaplastik tiroid kanserleri için ortalama sağkalım süresi 6-8 ay civarında olarak bildirilmektedir $(14,15)$. Total tiroidektomi ve radyoaktif iyot tedavisi sayesinde PTK ve FTK hastalarının çoğunda komplet klinik remisyon sağlanabilmektedir. Bununla birlikte mükemmel prognozlarına rağmen her hastada risk faktörleri iyi değerlendirilmelidir $(15,16)$. PTK'nın ağırlıklı olduğu çalışmamızda lenf nodu ya da uzak metastazın oldukça az olduğu $(\% 18,6)$ görüldü.

\section{SONUÇ}

Tiroid kanserleri genellikle kadın cinsiyette asemptomatik olarak karşılaştığımız prognozu oldukça iyi olan malign tümörlerdir. Bulgularımıza göre ülkemizde, görüntüleme yöntemlerinin gelişmesiyle bu tümörlerin erken teşhisi oldukça artmıștır. Tiroid kanserleri ile ilgili sonuçlarımızın literatür verileri ile benzer olması ülkemizde tiroid tümörlerinin yönetiminin başarıyla yapıldığını göstermesi açısından önemlidir.

\section{ETİK BEYANLAR}

Etik Kurul Onayı: Çalışmamız için Kırıkkale Üniversitesi Girişimsel Olmayan Etik Kurulu'ndan onay alınmıştır (2020.11.03).

Aydınlatılmış Onam: Çalışma retrospektif olarak dizayn edildiği için hastalardan aydınlatılmış onam alınmamıştır.

Hakem Değerlendirme Süreci: Harici çift kör hakem değerlendirmesi.

Çıkar Çatışması Durumu: Yazarlar bu çalışmada herhangi bir çıkara dayalı ilişki olmadığını beyan etmişlerdir.

Finansal Destek: Yazarlar bu çalışmada finansal destek almadıklarını beyan etmişlerdir.

Yazar Katkıları: Yazarların tümü; makalenin tasarımına, yürütülmesine, analizine katıldığını ve son sürümünü onayladıklarını beyan etmişlerdir.

\section{KAYNAKLAR}

1. Lamartina L, Grani G, Durante C, Filetti S, Cooper DS. Screening for differentiated thyroid cancer in selected populations. Lancet Diabetes Endocrinol 2020; 8: 81-8.

2. Singh Ospina N, Iñiguez-Ariza NM, Castro MR. Thyroid nodules: diagnostic evaluation based on thyroid cancer risk assessment. BMJ 2020; 368: 16670.

3. Roman BR, Morris LG, Davies L. The thyroid cancer epidemic, 2017 perspective. Curr Opin Endocrinol Diabetes Obes 2017; 24: 332-6.

4. Lamartina L, Grani G, Durante C, Borget I, Filetti S, Schlumberger M. Follow-up of differentiated thyroid cancer - what should (and what should not) be done. Nat Rev Endocrinol 2018; 14: 538-51.

5. Bibbins-Domingo K, Grossman DC, Curry SJ, et. al. Screening for thyroid cancer: US Preventive Services Task Force recommendation statement. JAMA 2017; 317: 1882-7.

6. Valderrabano P, Khazai L, Thompson ZJ, et al. Cancer Risk Stratification of Indeterminate Thyroid Nodules: A Cytological Approach. Thyroid 2017; 27: 1277-4.

7. Mitro SD, Rozek LS, Vatanasapt P, et al. Iodine deficiency and thyroid cancer trends in three regions of Thailand, 1990-2009. Cancer Epidemiol 2016; 43: 92-9.

8. Roman BR, Morris LG, Davies L. The thyroid cancer epidemic, 2017 perspective. Curr Opin Endocrinol Diabetes Obes 2017; 24: 332-6.

9. Haugen BR, Alexander EK, Bible KC, et al. 2015 American thyroid association management guidelines for adult patients with thyroid nodules and differentiated thyroid cancer: the American thyroid association guidelines task force on thyroid nodules and fifferentiated thyroid cancer. Thyroid 2016; 26: 1-133.

10. Carling T, Ocal IT, Udelsman R. Special variants of differentiated thyroid cancer: does it alter the extent of surgery versus welldifferentiated thyroid cancer? World J Surg 2007; 31: 916-23.

11.Saravana-Bawan B, Bajwa A, Paterson J, McMullen T. Active surveillance of low-risk papillary thyroid cancer: A meta-analysis. Surgery 2020; 167: 46-55.

12. Perri F, Giordano A, Pisconti S, et al. Thyroid cancer management: from a suspicious nodule to targeted therapy. Anticancer Drugs. 2018; 29: 483-90. 
13. Elisei R, Pinchera A. Advances in the follow-up of differentiated or medullary thyroid cancer. Nat Rev Endocrinol 2012; 8: 466-75.

14. Gweon HM, Son EJ, Kim JA, Youk JH. Predictive factors for active surveillance of subcentimeter thyroid nodules with highly suspicious US features. Ann Surg Oncol 2017; 24: 1540-45.

15. Ito Y, Miyauchi A, Oda H. Low-risk papillary microcarcinoma of the thyroid: a review of active surveillance trials. Eur J Surg Oncol 2018; 44: 307-15.

16. Sanabria A. Active surveillance in thyroid microcarcinoma in a Latin-American cohort. JAMA Otolaryngol Head Neck Surg 2018; $144: 947-8$. 